\title{
A Structural Analysis of Section 29(b) of the Securities Exchange Act
}

\author{
Dennis M. Black $\dagger$
}

On January 3, 1984, Pennzoil and three Getty entities-the Getty Oil Co. and the two major Getty Oil shareholders, the Sarah C. Getty Trust and the J. Paul Getty Museum ${ }^{1}$-agreed to a contract through which Pennzoil would obtain a three-sevenths interest in Getty Oil. At the time Pennzoil and Getty reached this agreement, Pennzoil had an outstanding tender offer to purchase Getty Oil stock at a lower price per share than the eventual contract price. Under the Pennzoil/Getty contract, all Getty Oil shareholders were to receive the higher contract price, but the J. Paul Getty Museum was to receive its money before the other shareholders. ${ }^{2}$

Texaco, knowing that Pennzoil and Getty had reached this contract, $^{3}$ nonetheless decided to take over Getty. Texaco knew that Gordon Getty, the trustee of the Sarah C. Getty Trust, could not under the trust agreement sell the Trust shares unless they were in danger of incurring a loss." Thus, Texaco first reached an agreement to purchase the Getty Museum's shares. Next, Texaco told Mr. Getty that they planned to launch a tender offer for the publicly held Getty shares. Texaco pointed out to Mr. Getty that if he did not sell the Trust's shares to Texaco, the shares would decline significantly in value because the Trust would be relegated from dominant shareholder to permanent minority shareholder. The Trust then agreed to sell its shares to Texaco. ${ }^{5}$ Texaco indemnified all Getty entities from any claims that they breached their contract with Pennzoil. ${ }^{6}$

Pennzoil sued Texaco for tortiously interfering with the

† B.S. 1986, Texas A \& M University; J.D. 1989, The University of Chicago.

1 The Getty entities are subsequently referred to collectively as "Getty" except where context makes an individual actor important.

2 Texaco, Inc. v Pennzoil, Co., 729 SW2d 768, 806 (Tex App 1987) (writ ref'd by Supreme Court of Texas, no reversible error, Nov 2, 1987).

3 Id at 803 .

- Id at 801,804 .

B Id at $801,804-05$.

- Id at 800, 802-03. 
Pennzoil/Getty contract. A Texas jury found that Texaco had interfered with the contract and awarded $\$ 7.53$ billion in compensatory damages and $\$ 3$ billion in punitive damages. ${ }^{7} \mathrm{~A}$ unanimous Texas appeals court affirmed the judgment, but found that the punitive damages were excessive, and suggested a remittitur of $\$ 2$ billion. ${ }^{8}$ On appeal to the Texas Supreme Court, Texaco, supported by the Securities Exchange Commission ("SEC") as amicus curiae, ${ }^{9}$ contended that the Pennzoil/Getty contract constituted an "arrangement to purchase" stock "otherwise than pursuant to [an outstanding] tender offer" in violation of SEC Rule 10b-13.10 Courts have interpreted SEC rules to allow stock purchases outside a tender offer when all tendering shareholders receive equivalent compensation to that provided in the "outside" contract.1" Texaco argued, however, that an earlier payment to the Getty Museum constituted preferential treatment in violation of Rule 10b-13. ${ }^{12}$ Thus, Texaco claimed that, pursuant to $\S 29(\mathrm{~b})$ of the Securities Exchange Act of $1934^{13}$ ("1934 Act"), the contract was "void . . . as regards the rights of" Pennzoil, and Texaco deprived Pennzoil of no enforceable rights.

Although Texaco also raised the 29(b) claim before the Texas Court of Appeals, that court accepted Pennzoil's argument that "Texaco is not a party whom ... rule [10b-13] is intended to protect in any way," and thus, "Texaco has no standing to assert . . . rule [10b-13], and we may not speculate on whether a proper party

7 Id at 784.

' Id at 866.

- See Brief of the Securities and Exchange Commission, Amicus Curiae, In' the Supreme Court of Texas, Texaco, Inc. $v$ Pennzoil, Co., On Application for a Writ of Error, No C-6432, (July 1987).

1017 CFR $\S 240.10 \mathrm{~b}-13$ (1988). The rule provides in pertinent part that:

No person who makes a cash tender offer ... for any equity security shall, directly or indirectly, purchase, or make any arrangement to purchase, any such security . . otherwise than pursuant to such tender offer ... from the time such tender offer is publicly announced or otherwise made known by such person to holders of the security to be acquired until the expiration of the period ... during which securities tendered pursuant to such tender offer ... may by the terms of such offer be accepted or rejected.

${ }^{11}$ See, for example, Wellman $v$ Dickinson, 475 F Supp 783 (S D NY 1979), aff'd 682 F2d 355 (2d Cir 1982).

12 Texaco's Application for a Writ of Error, In the Supreme Court of Texas, Texaco, Inc. $v$ Pennzoil, Co., No C-6432 at 115-17 (June, 1987). Pennzoil disputed that any violation of Rule 10b-13 had occurred. Pennzoil's Reply to Texaco's Application for a Writ of Error, In the Supreme Court of Texas, Texaco, Inc., v Pennzoil, Co., No C-6432 at 117-35 (August, 1987).

${ }^{13} 15$ USC $\S 78 c c(b)$ (1982), (quoted in full at text accompanying note 20 ). 
would have successfully asserted it."14 Because it found that Texaco did not have standing to obtain an adjudication of whether the Pennzoil/Getty contract violated Rule 10b-13, the Texas Appeals Court did not analyze whether $\S 29(\mathrm{~b})$ would have provided Texaco with a valid defense in the tortious interference action. The Supreme Court of Texas, finding no reversible error, declined to hear Texaco's appeal. Subsequently, the two companies settled the case for a record $\$ 3$ billion. ${ }^{15}$

These adverse decisions from the Texas courts extinguished Texaco's state law claims. Thus, if it had elected to press its appeal to the U.S. Supreme Court, Texaco would have been able to rely only on federal law arguments and primarily on its claim that the Pennzoil/Getty contract was void under $\S 29(\mathrm{~b})$. As a result of the Texaco/Pennzoil settlement, the Supreme Court did not decide the effect of $\S 29(\mathrm{~b})$ on Pennzoil's tortious interference claim. Nonetheless, the case shows the potential importance of this much ignored provision of the 1934 Act.

Section 29(b) applies to all provisions of the 1934 Act; it can be used to void any contract "made in violation of ... [or] the performance of which involves the violation of," any provision of the 1934 Act or any rule passed pursuant to it. ${ }^{16}$ The effects of this voiding provision are potentially great. For example, had the Pennzoil/Getty deal gone through, a subsequent challenge to the acquisition based on Pennzoil's possible violation of Rule 10b-13 might have voided a multi-billion dollar merger.

Despite the obvious importance of $\S 29(\mathrm{~b})$, it has received little attention from commentators ${ }^{17}$ or from the Supreme Court. ${ }^{18}$ As a result, it is not clear who can invoke $\S 29(\mathrm{~b})$ in a given case or what effect it should have when invoked. This comment addresses these two issues and examines the Texaco case within the pro-

14 Texaco, 729 SW2d at 806-07. The SEC chose to address neither the question of standing nor whether Texaco waived its § 29(b) defense by failing to obtain necessary jury findings. SEC Brief Amicus Curiae at $16 \mathrm{n} 18$ (cited in note 9). It was concerned solely with whether there had been a Rule $10 \mathrm{~b}-13$ violation and not whether such a violation would give a third party such as Texaco a defense pursuant to $\S 29(\mathrm{~b})$. Consequently, it took "no position as to the outcome of this case." Id at 4. 1988).

${ }^{16}$ See Texaco Pays Pennzoil, Leaves Bankruptcy, Chicago Tribune § 3, 3 (April 8,

18 15 USC $\S 78 \mathrm{cc}(\mathrm{b})$ (quoted in full in text accompanying note 20 ).

17 Only one scholarly article analyzes $\$ 29(b)$ in depth. Samuel H. Gruenbaum and Marc I. Steinberg, Section 29(b) of the Securities Exchange Act of 1934: A Viable Remedy Awakened, 48 Geo Wash L Rev 1 (1979).

${ }^{28}$ The Supreme Court has interpreted $\$ 29(\mathrm{~b})$ in only one case: Mills $v$ Electric AutoLite, 396 US 375 (1970). 
posed framework for analyzing $\S 29$ (b).

Section I of the comment discusses Mills $v$ Electric AutoLite ${ }^{19}$ the one decision in which the Supreme Court has discussed $\S 29(b)$. In Mills, the Court enunciated only the general principles governing $\S 29(\mathrm{~b})$; the case thus provides little guidance to lower courts as to how the provision should be applied in the disparate contexts in which it might be raised. Therefore, section II of the comment details several factors a court should consider when applying $\S 29(\mathrm{~b})$, and lays out a general framework for analyzing the different fact patterns in which $\S 29$ (b) may be invoked.

There are two additional issues that courts sometimes must deal with in the context of a $\$ .29$ (b) claim-fashioning the proper remedy and deciding the applicability of state law defenses. Section III of the comment addresses the proper remedies for successful $\S 29$ (b) claims. It argues that $\S 29(\mathrm{~b})$ should be interpreted as providing a flexible, equitable remedy. Finally, section IV analyzes the interplay between $\S 29(\mathrm{~b})$ and the state law defense of illegality which might be raised in a breach of contract action. This section argues that federal securities laws, specifically $\S 29(\mathrm{~b})$, exclusively govern the consequences of illegality under the federal securities laws and that state illegality defenses are therefore irrelevant in this context.

\section{Mills v Electric Auto LITE. The CuRrent View of § 29(B)}

Section 29(b) of the Securities Exchange Act of 1934 provides in relevant part that:

Every contract made in violation of ... [or] the performance of which involves the violation of ... a any provision of this chapter or any rule or regulation thereunder, shall be void ... as regards the rights of any person who, in violation of any such provision, rule, or regulation, shall have made or engaged in the performance of any such contract . . . .

There are, of course, many "provisions" of the 1934 Act and many "rules or regulations" passed pursuant to it. Section $29(\mathrm{~b})$ is thus potentially applicable to widely divergent situations involving misleading proxy statements, ${ }^{21}$ fraudulent disclosure forms, ${ }^{22}$ tender

\footnotetext{
19 Id.

2015 USC \& 78cc(b) (1982).

2117 CFR \& 240.14a-9 (1988).

2217 CFR \& 240.10b-5 (1988).
} 
offers, ${ }^{23}$ margin trading, ${ }^{24}$ and any other activity covered by the 1934 Act and its amendments. Surprisingly, the Supreme Court has not had a chance to apply $\S 29(\mathrm{~b})$ in these various contexts. Mills $v$ Electric Auto-Lite, ${ }^{25}$ the only Supreme Court case discussing $\S 29(\mathrm{~b})$ in any detail, presents only one application of the provision.

In Mills, the plaintiffs claimed that the Electric Auto-Lite company had violated rule $14 a-9^{26}$ which prohibits misleading proxy solicitations. Electric Auto-Lite had solicited proxies for a vote on a proposed merger without disclosing that all of the AutoLite directors were nominees of the acquiring company and that the acquirer was already the majority stockholder in Auto-Lite. The Supreme Court held that the proxy solicitation violated rule $14 \mathrm{a}-9$ and remanded the case to the district court to determine the appropriate relief. ${ }^{27}$

In remanding, the Court discussed the possibility of invoking $\S$ 29 (b) to void the merger agreement. It first validated the view of most lower courts ${ }^{28}$ that $\S 29(b)$ does not make contracts void ab initio:

We do not read $\S 29(b)$ of the Act . . . as requiring that the merger be set aside simply because the merger agreement is a "void" contract. This language establishes that the guilty party is precluded from enforcing the contract against an unwilling innocent party, but it does not compel the conclusion that the contract is a nullity, creating no enforceable rights in a party innocent of the violation. ${ }^{29}$

Thus, §29(b) grants an "unwilling innocent" party a defense to a breach of contract action brought by a guilty party. It also provides an affirmative cause of action:

The lower federal courts have read $\S 29(\mathrm{~b})$... as rendering the contract merely voidable at the option of the innocent party. This interpretation is eminently sensible. The interests of the victim are sufficiently protected by giving him the right

23 17 CFR § 240.10b-13 (1988); 17 CFR §§ 240.14d-1, et seq (1988).

${ }^{24} 12$ CFR $\S 220.1$ et seq (1988).

2s 396 US 375 (1970).

28 17 CFR § 240.14a-9 (1988).

${ }^{27}$ Mills, 396 US at 384-85, 389.

${ }^{28}$ See, for example, Greater Iowa Corp. $v$ McClendon, 378 F2d 783 (8th Cir 1967); Royal Air Properties, Inc. v Smith, 312 F2d 210 (9th Cir 1962); Bankers Life \& Cas. Co. $v$ Bellanca, 288 F2d 784 (7th Cir 1961).

20 Mills, 396 US at $386-87$ (footnotes omitted). 
to rescind. ${ }^{30}$

The Court reached a similar conclusion in Transamerica Mortgage Advisors, Inc. $v$ Lewis ${ }^{31}$ decided under a provision of the Investment Advisors Act of 1940 that is virtually identical to $\S 29(\mathrm{~b}) .^{32}$ The Court held that the voiding provision at issue "implie[d] a right to specific and limited relief. . . . At the very least Congress must have assumed that $\S 215$ could be raised defensively in private litigation to preclude the enforcement of an investment advisers contract."33 In addition, "[a] person with the power to avoid a contract ordinarily may resort to a court to have the contract rescinded and to obtain restitution of consideration paid."34

Thus, under Mills and Transamerica, § 29(b) provides two related rights to an "unwilling innocent" party to a contract that violates securities laws. First, it provides a defense to a breach of contract action. Second, it provides a right to rescind the contract and seek restitution. But it is unclear whom the "unwilling innocent" party standard of Mills encompasses. The Court did not define the terms "unwilling" and "innocent." In addition, the Court examined $\S 29(b)$ in light of only a single fact situation. Thus, its interpretation provides little guidance and may not govern all cases that could arise under the section.

Voiding a contract is an equitable remedy. Thus, at a basic level, the question of who can void a contract pursuant to $\S 29(\mathrm{~b})$-who is an "unwilling innocent" party-is an equitable question: Would it be fair to allow the non-violating party to void the contract? One pair of commentators suggests that knowledge of the violation precludes the right to relief:

An unwilling innocent party ... would probably be someone who did not have knowledge of the violation, as a willing innocent party would seem to include a party who had knowledge, but who could not be held to have violated the law. Accordingly, actual knowledge of the violation apparently would pre-

${ }^{30}$ Id at 387-88 (citations omitted).

31444 US 11 (1979).

${ }^{32} 15$ USC $\$ 80 \mathrm{~b}-15(\mathrm{~b})$ provides in relevant part:

Every contract made in violation of ... [ [or] the performance of which involves the violation of ... any provision of this subchapter, or any rule, regulation, or order thereunder, shall be void ... as regards the rights of any person who, in violation of any such provision, rule, regulation, or order, shall have made or engaged in the performance of any such contract. . . .

${ }^{33}$ Transamerica, 444 US at 18.

34 Id. 
clude the right to relief under $\S 29(\mathrm{~b}) .^{35}$

However, this reasoning may not apply under a rule designed to prevent coercive, rather than fraudulent, activity. ${ }^{36}$ An injured party could know of the rule violation and still be coerced into going along. This is exactly the type of behavior that such a rule was designed to prevent. Surely, in this situation, knowledge of a rule violation would not of itself preclude the voiding of the contract.

Given the extensive scope of the securities laws, it is doubtful that any per se rule regarding $\S 29(\mathrm{~b})$ could apply across the board. Section 29(b) advances no substantive policy of its own. It neither prohibits nor requires specific conduct. No one can "violate" $\S 29$ (b). Instead, it imposes an additional sanction for violations of other rules contained in or passed pursuant to the 1934 Act. Before $\S 29$ (b) can come into play, then, another rule must have been violated. Since these other rules have widely divergent purposes, it makes sense to interpret $\S 29(\mathrm{~b})$ with these substantive rules in mind. Specifically, in each case, courts should interpret $\S 29(\mathrm{~b})$ to advance the policy underlying the substantive rule that has been violated. ${ }^{37}$ The following section examines how courts should undertake such interpretations in the various fact patterns that arise under $\S 29(\mathrm{~b})$.

\section{A FramewORK FOR ANALYZING § 29(B)}

Securities rules and regulations can be divided into two basic types: 1) Market protection rules-rules primarily designed to promote confidence in the market as a whole, without any real concern for the individual participants in the activity being regulated; and 2) Individual protection rules-rules primarily designed to

${ }^{35}$ Gruenbaum and Steinberg, 48 Geo Wash L Rev at 13-14 n 65 (cited in note 17). In Blue Chip Stamps v Manor Drug Stores, 421 US 723 (1975), the Court makes passing reference to the fact that $\S 29$ (b) makes contracts "voidable at the option of the deceived party." 421 US at 735 (emphasis added). This is fleeting dictum, however, and may only have been meant to apply in the context of Rule 10b-5, where fraud is central. Gruenbaum and Steinberg claim that Blue Chip Stamps supports their actual knowledge standard because "[s]urely a party who has knowledge of the violation cannot be a deceived party." 48 Geo Wash L Rev at $13 \mathrm{n} 65$.

${ }^{36}$ Rule 10b-13, for example, is designed to discourage stock purchases outside of outstanding tender offers. Such purchases could create great pressure for shareholders to tender their shares in order to avoid a future decrease in value from a change in control or similar corporate restructuring.

s7 See Occidental Life Ins. Co. of No. C. $v$ Pat Ryan \& Assoc., Inc., 496 F2d 1255, 1266 (4th Cir 1974) (". . . Section 29 (b) is more properly viewed as an adjunct to the other remedies provided by the Securities Exchange Act of 1934 ... [and] should be read as complementing those remedies available to injured parties and not as being antagonistic."). 
benefit or protect a discrete group of individuals and that have only a subsidiary interest in promoting confidence in the market as a whole. ${ }^{38}$ If a rule is intended to protect a given individual, that individual's interests should be an important consideration in determining whether and how to invoke $\S 29(\mathrm{~b})$. If, on the other hand, the rule is designed to protect the general market, the focus shifts to minimizing rules violations and individual interests become less important.

\section{A. $\S 29(\mathrm{~b})$ and Market Protection Rules}

The Supreme Court has indicated that it is particularly reluctant to recognize implied private rights of action when a statute is designed to protect the public at large. ${ }^{38}$ This reluctance also makes sense in the context of applying $\S 29(\mathrm{~b})$ to market protection rules. Voiding a contract is an equitable remedy; when the person seeking to void the contract has not been injured in any legally important sense, the equities in that person's favor are not strong. The only policy reason, then, for voiding the contract would be to aid the market by deterring violation of the market protection rule. However, allowing a technically non-violating party to void contracts might actually increase the incidence of rules violations if that party is in a position to induce another party to the contract to violate the rules. Allowing non-violating parties to void the contract gives them the incentive to enter contracts that violate rules, with the intention of using $\S 29(\mathrm{~b})$ to void the contract if it turns out to their disadvantage.

One example of a market protection rule where such behavior might occur is Regulation $\mathrm{U}^{40}$ which regulates bank loans used to

${ }^{38}$ The distinction between laws aimed at the individual and laws aimed at the public good is not unique to securities regulation. In Cannon v University of Chicago, 441 US 677, 690-92 n 13 (1979), the Supreme Court recognized this distinction in another context, noting that "[t]his Court has never refused to imply a cause of action where the language of the statute explicitly conferred a right directly on a class of persons that included the plaintiff in the case. ... Conversely, the Court has been especially reluctant to imply causes of actions under statutes that create duties on the part of persons for the benefit of the public at large."

so Id.

to 12 CFR § 221 (1988). Regulation U provides in relevant part that "No bank shall extend any purpose credit, secured directly or indirectly by margin stock, in an amount that exceeds the maximum loan value of the collateral securing the credit." 12 CFR $\S 221.3$. "Purpose credit" is defined as "any credit for the purpose . . of buying or carrying margin stock." 12 CFR § 221.2(k). "Margin stock" is any "equity security registered or having trading privileges on a national securities exchange," and five other types of securities. 12 CFR \& 221.2(h). "Maximum loan value" is defined as "the percentage of current market value assigned by the [Federal Reserve] Board under [12 CFR] § 221.8 of this part to specified types 
purchase stock. The regulation requires that if a loan for the purchase of stock is to be secured by other stock, the loan cannot exceed 50 percent of the current market value of the stock being used as collateral. ${ }^{41}$ For example, if a borrower wanted to secure a bank loan to purchase stock with stock worth $\$ 10,000$, the loan could not exceed $\$ 5,000$.

Two policy concerns underlie Regulation U:

One concern was that credit-financed securities speculation at times diverted financial resources from more productive uses in commerce, industry, and agriculture. In addition, the Congress concluded that such activities created or reinforced tendencies for "bubbles" to occur in the stock market, with share prices first rising well above intrinsic values, and then collapsing as speculators with highly leveraged positions rushed to sell and as those providing securities credit called the loans. ${ }^{42}$

Thus, Regulation $U$ is not designed to protect the parties to the loan or any other discrete group. Instead, it is designed to protect the market from the perceived dangers of widespread purchases of stock on credit. ${ }^{43}$

One can divide situations in which Regulation $U$ is violated into three types: first, where the borrower is ignorant of the exis-

of collateral." 12 CFR § $221(\mathrm{i})$.

41 12 CFR \& 221.8(a).

62 A Review and Evaluation of Federal Margin Regulations: A Study by the Staff of the Board of Governors of the Federal Reserve System 2-3 (December 1984). Broker and borrower protection were not primary goals of margin requirements, though policy makers are presently concerned with protecting the former and Congress realized that protection of the latter would be a by-product of the regulation. Id at 6, 126-27. See also HR Rep No 1383, 73d Cong, 2d Sess, 8 (1934):

The main purpose of these margin provisions ... is not to increase the safety of security loans for lenders. ... Nor is the main purpose even protection of the small speculator by making it impossible for him to spread himself too thinly-although such a result will be achieved as a by-product of the main purpose. . . . The main purpose is to give a Government credit agency an effective method of reducing the aggregate amount of the nation's credit resources which can be directed by speculation into the stock market and out of other more desirable uses of commerce and industry ....

43 Until 1983, regulation U did not apply to the borrower. If a loan did not meet the margin requirements of the Federal Reserve, the bank was the only violating party. In 1983, the Federal Reserve promulgated Regulation X, 12 CFR $\$ 224$, prohibiting borrowers from "willfully caus[ing] credit to be extended in contravention of Regulation [U]." 12 CFR § 224.3(b). This provision prevents a willful violator of Regulation X from taking advantage of a bank's concomitant Regulation U violation by voiding the loan under $\S 29(\mathrm{~b})$. However, since Regulation X did not exist when the cases discussed in this comment were decided and since the relatively large number of cases decided under Regulation $U$ make it a good example of the interplay of market protection regulations with $\S 29(\mathrm{~b})$, Regulation X will be ignored. 
tence of margin regulations ${ }^{44}$ and a bank loans money in contravention of Regulation U; second, where the borrower misleads the bank as to the true purposes for the loan and later seeks to rescind the loan because of the Regulation $U$ violation; and, third, where a third party claims to have been injured by a loan that violates Regulation $U$ and seeks to void the transaction.

1. Unwilling innocent party.

The first fact situation involves an investor who is unaware that federal regulations limit the amount of money that can be loaned for the purchase of stock when other stock secures the loan. Grove $v$ First National Bank of Herminie is typical of this type of case. ${ }^{45}$ In Grove, the plaintiff was not aware that margin requirements existed, while the "[b]ank had constructive as well as actual knowledge ... that the proceeds of the loans were being used by plaintiff almost totally for the purpose of carrying or purchasing registered securities."46 The loans to the plaintiff violated Regulation $U$ because they exceeded the applicable percentage of the value of the stock being used as collateral. The court allowed Grove to avoid liability on the loan under $\S 29(\mathrm{~b}) .^{47}$

This holding follows the "unwilling innocent" investor rule of Mills. Regulation U puts, if not "the entire burden of observing the margin requirements on the lender,"48 then at least the majority of the burden. Banks should be required to make at least minimum efforts to comply with the regulation, a duty that the bank in Grove did not fulfill. ${ }^{49}$ When one party is not even aware that margin rules exist, and thus innocent of any complicity, that party should be allowed to use $\S 29(\mathrm{~b})$ to void the transaction. In the context of Regulation $\mathrm{U}$, voiding insures minimum compliance by the bank, the party presumed to have greater knowledge.

\section{Willing innocent party.}

The second fact pattern occurs when the "innocent" party is in some way culpable in the rule violation, such as where the bor-

14 Thus, the borrower would not be a violator of Regulation $\mathrm{X}$ which requires willfulness.

45 489 F2d 512 (3d Cir 1973).

to Id at 513-14.

47 Id at 515-16.

48 Serzysko $v$ Chase Manhattan Bank, 290 F Supp 74, 77 (S D NY 1968), aff'd, 409 F2d 1360 (2d Cir 1969).

19 Grove, 489 F Supp at 513. 
rower knows of the existence of margin regulations and misleads the lender as to the reason for the loan. Regulation $U$ exempts "mistake[s] in good faith" from coverage. ${ }^{50}$ Thus, innocent lenders who exercise due diligence, but could not reasonably have been expected to discover the borrower's intended use of the money, do not violate the Regulation. In such a case, a borrower could not invoke $\S 29(\mathrm{~b})$ to void a loan because there would be no rule violation.

The difficulty arises when a borrower lies to the bank about the purpose of the loan and the bank negligently fails to discover the deception. Courts faced with this situation have split over whether to allow the borrower to invoke § 29(b) and avoid the duty of paying back the loan. No court has allowed the borrower to recover damages. In Serzysko v Chase Manhattan Bank, the court acknowledged that " $[t]$ he law tends to look with a jaundiced eye upon the claim of a deceiver that his victim should not have been deceived." It found, however, that "[i]f an investigation had been made [by the bank] it would have revealed that the plaintiff, contrary to his oral and written statements, was making use of the proceeds of some of the loans to purchase or carry registered securities." ${ }^{2}$ Because the bank failed to exercise reasonable diligence, the court found that it had violated Regulation U. It allowed the borrower to void the loan under $\S 29(\mathrm{~b})$ and refused to allow the bank to recover any unrepaid money on it. ${ }^{.3}$

The court in Goldman $v$ Bank of Commonwealth, ${ }^{54}$ faced with a similar fact situation, attempted to punish both parties. It allowed the bank to recover the amount of the loan but did not allow it to recover any interest..5 It found that "[t]he worst that can be said about the Bank is that it did not exercise ordinary banking procedures," while the borrower acted intentionally and "was the aggressor in the loan transactions." The result in Serzysko appears clearly wrong. Regulation U exists because margin loans are

${ }^{\text {so }}$ See 12 CFR § 221.3(k).

${ }^{31} 290$ F Supp 74, 90 (S D NY 1968), aff'd 409 F2d 1360 (2d Cir 1969).

52 Id.

s3 Id. See also Grove, 489 F2d at 516 ("recovery [of loans by bank] may be precluded [by $\S 29(\mathrm{~b})$ ] even if the borrower knowingly and intentionally deceives the bank as to the actual purposes of the loans"). It is these cases that Regulation X will most effect. Since Regulation X makes a borrower who willfully induces a violation of Regulation $U$ a violating party also, it is unlikely a court today would allow such a borrower to invoke $\S 29(\mathrm{~b})$. See Gruenbaum and Steinberg, 48 Geo Wash L Rev at $5 \mathrm{n} 18$ (cited in note 17).

s4 467 F2d 439 (6th Cir 1972).

ss Id at 441 .

so Id at 447. 
considered potentially harmful. In Serzysko, however, in order to deter inadvertent, albeit negligent, conduct by the bank, the court affirmatively encouraged fraudulent conduct by the borrower. This will surely result in more violations of Regulation $U$, as borrowers have everything to gain and nothing to lose from lying to banks about whether they intend to use borrowed money to purchase stock. At worst, the bank will discover the deception and refuse to loan the money, in which case the borrower would be no worse off. If the bank non-negligently fails to discover the deception, the borrower only has to repay the loan as planned. At best, the bank will negligently fail to discover the deception. Then the borrower can point to the Bank's Regulation U violation and refuse to repay the loan under $\S 29(\mathrm{~b})$. Any rule that encourages fraud to deter negligence is problematic.

The Second Circuit noted this problem in Pearlstein $v$ Scud$\operatorname{der} \&$ German, $^{57}$ a case decided under an analogous regulation ${ }^{58}$ governing brokers instead of banks. Nonetheless, the court concluded that "the danger of permitting a windfall to an unscrupulous investor is outweighed by the salutary policing effect which the threat of private suits" would have on brokers. ${ }^{59}$ This policing can be obtained, however, by allowing only innocent borrowers to void their transactions. The marginal enforcement gain from also allowing dishonest borrowers to do so seems slight. As Judge Friendly pointed out in his dissent, "[a]ny deterrent effect of threatened liability on the broker may well be more than offset by the inducement to violations inherent in the prospect of a free ride for the customer who, under the majority's view, is placed in the enviable position of 'heads-I-win tails-you-lose." "60

The same criticism can be levelled at the Goldman court, although it provides less incentive for fraud (and a concomitant lesser deterrent for negligence). When the bank negligently fails to discover deception, the borrower has to repay the loan but gets off without having to pay interest on the borrowed money. He thus gets free use of the money until the fraud is discovered. The preferred course when the "innocent" party is in some way guilty of violating a market protection rule is not to void the contract and

57429 F2d 1136 (2d Cir 1970).

${ }^{58}$ Regulation T, 12 CFR 220 (1988).

${ }^{88} 429$ F2d at 1141. Although Judge Friendly discussed $\S 29(\mathrm{~b})$ in his dissent, see id at 1149 , Pearlstein involved an action for damages and not an action to void a contract pursuant to $\S 29$ (b).

${ }^{\text {Bo }}$ Id at 1148 (Friendly dissenting). 
always to require that interest be paid by the deceptive borrower to the merely negligent lender.

The question might be closer if both parties acted intentionally, for in that case the equities favor neither party. Voiding the contract, however, would still provide incentives for the "innocent" party to engage in intentional wrongdoing. In this situation, the regulation should be enforced by the government agency charged with overseeing it (in the case of Regulation U, the Federal Reserve), ${ }^{61}$ rather than by the parties to the contract. Limiting enforcement in this way will deter the regulated party, but will not encourage the unregulated party to induce violations.

\section{Third party attempting to void loan.}

The least common fact pattern that arises under market protection rules occurs when a third party seeks to invoke $\$ 29(\mathrm{~b})$ because of an alleged injury caused by a rule violation. Such a case arose under Regulation U in Natkin v Exchange National Bank of Chicago. ${ }^{62}$ In Natkin, the plaintiffs endorsed in blank a number of stocks to be used by another person as security for a bank loan. The bank had no knowledge of the source of collateral. The plaintiffs later sued the bank for return of the stock, claiming that the loan violated Regulation $U$ and was thus void under $\S 29(\mathrm{~b})$. The Seventh Circuit affirmed the District Court's summary judgment for the defendants, holding that "[a]lthough a violation such as here alleged operates to void the contract rights of the party in violation ... there is nothing in the section which operates to create any right or cause of action against the party in violation in favor of a stranger to the contract."Bs

This is the correct result for three reasons. First, market protection rules in general, and Regulation $U$ in particular, were not promulgated to protect against particular injuries to third parties. Thus, not even third parties who can show injury can claim that the rule was passed for their "especial benefit." third parties to assert $\S 29$ (b) to void a contract to which they were not a party runs the risk of injuring an unwilling innocent party to the contract. Third, allowing third parties to void contracts creates

62 See id at 1147-48 (Friendly dissenting) (noting that isolated violations of margin regulations pose little threat, and when violations become widespread "we may confidently expect application of the administrative and criminal sanctions provided by the Act").

${ }^{62} 342$ F2d 675 (7th Cir 1965).

${ }^{63}$ Id at 676-77.

64 See text accompanying note 66 . 
an incentive for them to engage in strategic behavior designed merely to injure competitors. Given these considerations, enforcement by the appropriate government agency is always preferable to enforcement by third parties. ${ }^{6 s}$

\section{B. Section 29(b) and Individual Protection Rules}

It is in the area of individual protection rules that $\S 29(\mathrm{~b})$ comes into the greatest contact and possibly tension with the Supreme Court's jurisprudence governing implied statutory private rights of action. One part of the Court's test for implied rights of action asks whether the plaintiff is a member of the class for whose "especial benefit" the relevant statute was passed. ${ }^{66}$ In other words, is the plaintiff one of the individuals the rule was designed to protect. In the context of a contract-governing rule like $\S 29(\mathrm{~b})$, it is also important to ask whether the person seeking to void the contract is a party to the contract. For, it is possible that the intended beneficiary of a rule and the innocent party to the contract may not be the same person and that their interests might diverge. In addition, the intended beneficiaries of a rule may be a group of persons, such as shareholders in a corporation, some of whose interests are best served by voiding a contract and some of whose interests are best served by affirming it.

This subsection of the comment analyzes each of these possibilities separately. First, it examines the strongest case for voiding a contract-where the person invoking $\S 29(\mathrm{~b})$ is both a party to the contract and a member of the beneficiary group. Next it analyzes the case in which the person seeking to void the transaction is in privity, but is not the statutory beneficiary. Third, it examines the case in which the party who attempts to void the contract is a statutory beneficiary but is not in privity, and finally it analyzes the situation in which the party seeking to void a contract is neither the statutory beneficiary nor in privity. Since the parties

${ }^{6 s}$ In a case such as Natkin, the plaintiff is not left remediless. He dealt only with the person who took out the loan and can sue that person for return of the stock or for compensation. The case might be different if the third party officially guaranteed the loan and was ignorant of the Regulation $U$ violation. In that case, the bank would know the third party existed and by extending an excessive margin loan would be putting that person's collateral in a more risky position. In this situation, a court could more plausibly find that the bank had a duty to the third party, and thus might void the guarantee. See Stonehill $v$ Security National Bank, 68 FRD 24, 31-32 (S D NY 1975) for one court that found such a duty based on this line of reasoning.

${ }^{68}$ See Cort $v$ Ash, 422 US 66, 78 (1975). See also Assoc. of Data Processing v Camp, 397 US 150, 153-54 (1970) ("zone of interests" analysis for standing purposes). 
involved in each of these fact patterns have differing incentives and interests, the courts must use a somewhat different analysis for each of the four situations.

\section{Party both in privity and statutory beneficiary.}

Clearly the strongest case for invoking $\S 29(\mathrm{~b})$ is the situation where the party seeking to void the contract is both the person for whose benefit the relevant rule was passed and is in privity of contract with the violating party. Voiding such contracts benefits the statutory beneficiary at the expense of the law-breaking party with minimal risk of harming third parties. The innocent party may reap a windfall if the violating party has substantially performed his share of the contract, (especially when the innocent party has performed very little), but the court can adjust its remedy in such cases to make the outcome more equitable. ${ }^{67}$

Sundstrand Corp. $v$ Sun Chemical Corp. ${ }^{68}$ is typical of this type of case. Sundstrand claimed that defendant Huarisa had materially misrepresented various facts regarding a company (of which he was president and a substantial owner) with which Sundstrand was interested in merging. As part of an uncompleted merger agreement between the two, Sundstrand signed a stock option transfer agreement obligating it to repurchase 5,686 shares of Sundstrand stock from Huarisa on fifteen days written notice. The merger fell through when Sundstrand discovered Huarisa's misrepresentations. Huarisa gave notice pursuant to the transfer agreement, but Sundstrand refused to perform, alleging that Huarisa had violated the securities laws. Finding that Huarisa's actions violated Rule 10b-5, the court declared the contract "void as regards the rights of Huarisa under Section 29b."68

The facts in Sundstrand represent the strongest possible situation for invoking $\S 29(\mathrm{~b})$. Rule $10 \mathrm{~b}-5$ is designed to protect purchasers and sellers of securities from fraudulent misrepresentations. ${ }^{70}$ Sundstrand was a prior seller and current prospective purchaser who was induced to enter a contract by fraudulent misrepresentations. Voiding the contract prevented Huarisa, the violating party, from reaping any rewards from his fraudulent scheme. It resulted in no harm to innocent third parties and no windfall

${ }^{67}$ For a discussion of remedies, see section III.

os 553 F2d 1033 (7th Cir 1977).

69 Id at 1051.

7o See Blue Chip Stamps, 421 US at 754. 
gain to Sundstrand..$^{71}$

\section{Privity but not statutory beneficiary.}

The second fact pattern involves a party who is in contractual privity with the violating party but is not the intended beneficiary of the rule violated. The case of Thomas $v$ Duralite Co., Inc. ${ }^{72}$ is illustrative. In Thomas, misleading information about the profit prospects of Duralite, a closely held corporation, led Thomas, one of its shareholders, to sell all his shares in the company to a coshareholder.$^{73}$ In a contemporaneous transaction, Edco and Temco, two other closely held corporations in which Thomas had substantial investments, agreed to purchase certain materials from Duralite. Thomas sued for damages under Rule 10b-5, seeking the difference between the value he received for his stock and the true value of the stock. Edco and Temco claimed that since Duralite had violated Rule 10b-5, they could invoke $\S 29(\mathrm{~b})$ to void their agreement to purchase materials from Duralite. The district court held for Thomas on his 10b-5 claim and allowed Edco and Temco to void their agreement with Duralite pursuant to $\S 29(\mathrm{~b}) .{ }^{74}$ The district court ruled that " $[\mathrm{i}] \mathrm{n}$ recognition of the intimate relationship between Thomas and the Edco and Temco corporations existing at the execution of the June 18, 1968 agreement, Edco and Temco, as unwilling innocent parties to the defendants' fraudulent conduct in violation of Rule 10b-5, are entitled to rescind any and all of their obligations incurred under the aforementioned agreement."

The Second Circuit affirmed on the Rule $10 \mathrm{~b}-5$ violation, but reversed the district court's holding pertaining to $\S 29(\mathrm{~b})$ because Edco's and Temco's contract with Duralite was for the purchase of inventory rather than securities. Thus, "[b]eing neither purchasers nor sellers of securities, Edco and Temco have no standing under Rule 10b-5." "76

The Second Circuit failed to consider, however, that $\S 29(\mathrm{~b})$ might provide Edco and Temco an equitable right of action regardless of their standing under Rule 10b-5. The purchaser/seller

${ }^{71}$ The only time that voiding a contract at the behest of a statutory beneficiary/party to the contract may be ill-advised is if it results in a windfall gain to the voiding party. See Occidental Life, 496 F2d at 1267 (refusing to void contract where doing so would result in plaintiff "gain[ing] double its amount of damages. The result would hardly be equitable.").

${ }^{72} 524$ F2d 577 (3rd Cir 1975).

${ }^{73}$ Id at $580-83$.

74 Id at 583.

${ }_{75}$ Thomas $v$ Duralite Company, Inc., 386 F Supp 698, 730 (D NJ 1974).

${ }^{76} 524$ F2d at 590. 
standing requirement of Blue Chip Stamps v Manor Drug Stores applies only to private actions for damages under Rule 10b-5.77 Edco and Temco were seeking an equitable remedy under $\S 29(\mathrm{~b})$, not damages. The district court found that Edco and Temco's material purchases were related to the fraudulent stock sale. Both agreements were contained in one contract stating that "all the parties recognize that the sale and purchase of the stock in ... Duralite and the ... purchase of said inventory of Duralite by Edco and Temco are interrelated because of the relationship between the parties." "78 The district court found that [b]oth [Edco and Temco] were under the control of Thomas and his partner Edwards, and both entered into their contractual obligations to facilitate the extinction of Thomas' interest in . . . Duralite."79

If non-beneficiary parties like Edco or Temco can show that the contract they seek to void had a sufficient connection with a violation of the securities laws and that they were not culpable in the violation, then the court should allow them to use $\S 29(\mathrm{~b})$ to void the transaction. There is little danger of harming the statutory beneficiary by doing so, and the violating party merely loses the gains from a contract that illegal activity procured. Once again, the court can use its equitable powers to ensure that voiding the contract does not produce a windfall gain for the innocent party.

Temco's and Edco's position in this case is comparable to the Getty entities' position in Texaco. These entities were in privity of contract with Pennzoil, but were not intended beneficiaries of Rule 10b-13; instead, the tendering Getty shareholders were. ${ }^{80}$ There is one important difference between the cases, however. The Getty entities would have been aware of the rule violation since the contract was the result of negotiations between the Getty entities and Pennzoil. The essence of a Rule $10 \mathrm{~b}-13$ violation is making a "purchase, or . . . any arrangement to purchase [stock] otherwise than pursuant to" an outstanding tender offer, on terms different than the tender offer. ${ }^{81}$ Thus, the making of the contract itself

72 Blue Chip Stamps, 421 US at 727.

28 Thomas, 386 F Supp at 729.

79 Id at 729. The Second Circuit pointed out that "another portion of that same agreement provided that the purchase of the inventory was severable from the stock transaction." Thomas, 524 F2d at 589. This possible contradiction in the contract created at most a question of fact for the district court to resolve, and it is difficult to see how a factual finding that the agreements were related could be clearly erroneous.

so See Beaumont v American Can Co., 797 F2d 79, 84 (2d Cir 1986).

8117 CFR $\S 240.10 \mathrm{~b}-13$ (cited in full in note 10 ). Rule 10b-13 was designed "protect people who tender their shares pursuant to a tender offer by prohibiting the offeror from making 'outside' purchases (i.e., purchases on terms different from those in the tender of- 
would violate Rule $10 \mathrm{~b}-13$, and the Getty entities would have as much knowledge that the rule was being violated as would Pennzoil. Being so intimately involved in the possible rule violation, it would be inequitable to allow the Getty entities to escape their contract by asserting $\S 29(\mathrm{~b}) .^{82}$ Thus, while the Getty entities would satisfy the nexus requirement, they would fail the non-culpability requirement and should not be allowed to void the contract.

\section{Statutory beneficiary but not in privity.}

The third fact pattern involves a party who is the intended beneficiary of a rule that is violated but is not in privity of contract with the violating party. This is the opposite of the previous fact pattern and can occur whenever the rule violated is designed to protect shareholders, and the corporation in privity with the violating party is the one in which they own stock. The corporation may have changed ownership as a result of the contract and be unwilling to invoke $\S 29(\mathrm{~b})$, or it may be so intimately involved in the rules violation that it cannot invoke $\S 29(\mathrm{~b})$. This leaves the shareholders the option of suing for damages if they have a private right of action under the rule violated and/or attempting to void the contract under $\S 29(\mathrm{~b})$. While it is conceivable that an individual protection rule might be designed to protect an individual who could not even establish privity derivatively, such rules, if they exist, are rare. ${ }^{83}$ Therefore, we need only address the situation where a party can establish privity derivatively. The Supreme Court addressed this situation in Mills, a case in which minority shareholders of Electric Auto-Lite brought suit seeking to void a merger be-

fer)." Beaumont, 797 F2d at 84.

${ }_{82}$ The Getty Oil Company itself might argue that it should be able to invoke $\S 29(\mathrm{~b})$ on behalf of its shareholders-the intended beneficiaries of the rule. However, in such a situation the tendering shareholders should be allowed to decide for themselves whether or not to invoke $\S 29(\mathrm{~b})$. If Getty in fact participated in a rules violation that injured the tendering shareholders, Getty was not acting in the shareholders' best interests. There seems little reason to expect that it will necessarily be acting in their interests when it invokes $\S 29$ (b).

${ }^{83}$ Some insider trading rules governing corporate officers may be justified by the protection of shareholders of the corporation from the consequences of the perverse incentives such things as "selling short" might create. (i.e., if officers sold short, they would have an incentive to make the company lose money to depress stock values) The general shareholders would not be a party to the relevant contract (the officer's contract would be with a broker), nor would the corporation. Thus, although they may be the beneficiaries of some insider trading rules, the shareholders would not be able to establish privity even derivatively. For a critical discussion of the justifications for insider trading rules, see Dennis W. Carlton and Daniel R. Fischel, The Regulation of Insider Trading, 35 Stan L Rev 857 (1983). 
tween Auto-Lite and Mergenthaler under $\S 29(b)$. The plaintiffs claimed that Auto-Lite's management violated rule 14(a) $-9{ }^{84}$ which prohibits misleading proxy solicitations, by failing to disclose that Mergenthaler owned the majority of stock in Auto-Lite and that all eleven of Auto-Lite's directors were nominees of Mergenthaler. Both the district and appeals courts held that the failure to disclose these facts in the proxy statements soliciting votes for the merger was materially misleading. ${ }^{85}$

After laying out the "unwilling innocent" party standard, the Court analyzed the rights of the minority shareholders under $\S 29(\mathrm{~b})$. First, the Court noted that the minority shareholders were "not parties to the merger agreement and thus do not have a statutory right under $\S 29(\mathrm{~b})$ to set it aside." ${ }^{986}$ Next, the Court pointed out that "[i]f petitioners had submitted their own proxies in favor of the merger in response to the unlawful solicitation, as it does not appear they did, the language of $\S 29(\mathrm{~b})$ would seem to give them, as innocent parties to that transaction, the right to rescind their proxies."87 Finally, the Court held that minority shareholders

do have a derivative right to invoke Auto-Lite's status as a party to the agreement, [but] a determination of what relief should be granted in Auto-Lite's name must hinge on whether setting aside the merger would be in the best interests of the shareholders as a whole.... [T] he merger should be set aside only if a court of equity concludes, from all the circumstances, that it would be equitable to do so. ${ }^{88}$

This is generally a sound approach. Allowing shareholders to void their "mini-transactions" (i.e., their proxies) would cause a merger to be overturned whenever the rules violation is sufficiently harmful that enough proxies are withdrawn to change the outcome. This avoids the problems inherent in allowing one shareholder (or a small group) to set aside a merger under $\S 29(\mathrm{~b})$, irrespective of the wishes of the other shareholders. The latter rule would create a significant opportunity for strategic behavior and might not be in

84 17 CFR $\S 240.14 a-9$ (1988) provides in relevant part that "[n]o solicitation . . . shall be made by means of any proxy statement ... containing any statement which, at the time and in the light of circumstances under which it is made, is false or misleading with respect to any material fact, or which omits to state any material fact necessary in order to make the statements there in not false or misleading."

ss 396 US at $378-80$.

s6 Id at 388.

${ }^{87}$ Id at $388 \mathrm{n} 11$.

${ }^{88}$ Id at 388 . 
the interests of the shareholders as a whole.

Thus, the only problematic aspect of the Court's analysis in Mills is its veiled implication that a small number of shareholders might be able to invoke $\S 29(\mathrm{~b})$ to set aside a merger if a court decides that doing so is in the best interests of the shareholders. Shareholders are a diverse lot, and the Court gives no indication of how a judge is to determine their best interests as a whole. Since shareholders invest in stock for a number of reasons, voiding a transaction will have different effects on different shareholders, including disparate tax consequences and different effects on portfolio risk distribution. With most corporate transactions it will be impossible to determine whether shareholders as a whole would be better or worse off if the transaction were nullified..$^{89}$ Therefore, it is best to avoid the inquiry if possible.

Fortunately, the inquiry is unnecessary in many cases. First, in those cases in which individual shareholders can void their "minitransaction," they can decide for themselves whether the transaction was in their best interests. ${ }^{90}$ Second, in most cases where the shareholders are statutory beneficiaries, they will have a damage remedy that can obviate the need to search for equitable remedies. ${ }^{91}$ Only in those cases where a damage remedy is either unavailable or clearly inadequate and there are no "mini-transactions" to void should the court even consider whether the shareholders as a whole are better off. Such cases will be rare.

If the transaction had proceeded as Pennzoil planned, the tendering Getty shareholders would have been in this general situation. As tendering shareholders, they were the intended beneficiaries of Rule $10 \mathrm{~b}-13$, but were not in contractual privity with Pennzoil, the allegedly violating party. Thus, they might have had a right to invoke $\S 29(\mathrm{~b})$ and revoke their tender of shares if Pennzoil had in fact violated Rule 10b-13. If enough shareholders did so, the merger would be overturned. Following the dictum in Mills, a court might have allowed an individual shareholder or small group of shareholders to void the entire transaction by derivatively asserting the right that Getty's culpability barred it from

${ }^{89}$ Many of the same concerns have been used to justify the business judgment rule. See Daniel Fischel, The Business Judgment Rule and the Trans Union Case, 40 Bus Law 1437 (1985).

${ }^{30}$ This might be done by a class action seeking to void proxies given to management, for example. Those who chose to opt out of the class action would have chosen to affirm their proxies. See FRCP 23.

${ }^{21}$ For example, in the context of Rule $10 \mathrm{~b}-13$, the damage remedy would be the difference between the amount paid for the wrongful outside purchase and the tendered shares. 
asserting. The harshness of this result, however, would probably have kept a court from completely voiding the transaction. ${ }^{92}$

\section{Party neither in privity nor statutory beneficiary.}

The weakest case for invoking $\S 29(\mathrm{~b})$ arises when the party seeking to void the contract is neither the statutory beneficiary nor in privity with the alleged violating party. In this situation, the contract should not be voided. Greater Iowa Corp. $v$ McLendon ${ }^{93}$ is an example of this type of case. In Greater Iowa, shareholders dissatisfied with the management of the Greater Iowa Corporation formed the Iowa Trust, a voting trust with the "purpose of 'controlling or influencing control of The Greater Iowa Corporation." "94 The defendants traded "evidences of ownership" in the trust for shares of stock in the Greater Iowa Corporation. The plaintiffs were The Greater Iowa Corporation, its directors, and three non-director shareholders, none of whom had joined the Iowa Trust. The plaintiffs claimed that the promoters of the Iowa Trust violated Rule $10 \mathrm{~b}-5$ by making materially misleading statements in selling the "evidences of ownership" in the Trust, which the plaintiffs claimed were "securities" under the Act.

The Eighth Circuit denied the plaintiffs a private right of action under Rule 10b-5: "As plaintiffs are neither purchasers or sellers of the allegedly fraudulent security and were not the parties defrauded by a purchase or sale, they are not within the class afforded protection under the Act and implementing Rule." ever, the plaintiffs also invoked $\S 29(b)$ "assert[ing] the absolute voidness of the transfers of the Greater Iowa common stock to the Iowa Trust, and seek[ing] declaratory relief as to the rights created thereunder."97 The court also denied this line of attack:

[W]e believe the only private party capable of attacking the validity of these transactions between the Greater Iowa shareholders and the defendants are the shareholders who were allegedly defrauded. The guilty party cannot assert the invalidity of these contracts. Certainly, too, the plaintiffs, as strangers to the contracts, have no standing to inject them-

${ }^{22}$ See the discussion in section III of the extensive powers courts have to shape remedies under $\S 29(\mathrm{~b})$.

${ }^{93} 378$ F2d 783 (8th Cir 1967).

94 Id at 787.

os Id.

os Id at 791.

97 Id at 792. 
selves between contracting parties and assert the invalidity of transactions to which the contracting parties are apparently perfectly content to enter and observe. ... Any rights granted to defendants by these shareholders [those who had joined the Trust] must, at this time, be observed by the Greater Iowa Corporation. ${ }^{98}$

Given the purposes of Rule 10b-5, this is the correct result. The plaintiffs in this case were concerned not with the "deceptive" nature of the trust solicitations but with the threat to their continued control of the corporation. If the plaintiffs were truly concerned that the shareholders were being deceived, the plaintiffs could have communicated their version of the truth, and let the shareholders decide for themselves if they had been deceived. Those shareholders would then have had the opportunity to sue the Trust organizers under Rule $10 \mathrm{~b}-5$ or $\S 29(\mathrm{~b})$. Neither Rule 10b-5 nor $\S 29$ (b) was designed to guard against a manager's loss of control. Parties who are strangers to both the concern of the statutory scheme and the contract should have no right to litigate the alleged injuries and defalcations of others.

Texaco would have found itself in exactly this position had it sued for a declaratory judgment that the Pennzoil/Getty contract was void before taking the actions that were found to constitute tortious interference. Since Texaco was not a tendering shareholder it was not the intended beneficiary of the rule. It also was not a party to any relevant contract with Pennzoil or any Getty entity at that time.

Still, Texaco claimed that Pennzoil's "side deal" with the Getty Museum for a slightly earlier payment violated Rule 10b-13. That rule was promulgated pursuant to the 1968 Williams Act, an amendment to the 1934 Act that comprehensively regulates tender offers. In Piper $v$ Chris-Craft Industries, Inc., ${ }^{99}$ the Supreme Court concluded that when Congress regulated tender offers through the Williams Act, it intended to protect shareholders, not competing tender offerors. Unlike shareholders, competing tender offerors do "not come to the courts in the posture of a hoodwinked investor victimized by market manipulation."100 Indeed, granting such a right would be inconsistent with the Act's attempt to aid shareholders because " $[\mathrm{m}]$ ore likely . . . is the prospect that share-

98 Id.

99 430 US 1 (1977).

100 Id at 45 . 
holders may be prejudiced" by the fact that such a right would deter tender offers from ever being made. ${ }^{101}$

Piper was concerned with whether a competing tender offeror could maintain an action for damages, but its analysis of the effects of allowing such suits is applicable to $\S 29(b)$ as well. Tender offers would also be deterred if the potential tender offeror knew that third parties could void any resultant contract because of a violation of securities laws. If Congress conferred no rights upon competing tender offerors who could be injured by losing the battle for the target company and who have acted through legitimate mechanisms, then a fortiori, they did not intend to confer a right upon someone who tortiously interfered after a contract had already been reached. ${ }^{102}$ To create such a right could injure shareholders, who are the intended beneficiaries of the regulations, without advancing the statutory policy. Therefore, Texaco had no standing to invoke $\S 29(\mathrm{~b})$ to claim that the Pennzoil/Getty contract was void.

\section{REMEDIES UNDER § 29(B)}

Read literally, § 29(b)'s remedy can be extremely harsh-a complete voiding of any enforceable rights of the violating party. ${ }^{103}$ Giant corporate mergers could be wiped out by minor violations of the securities laws. A party who had already completely performed but who had violated a securities law could receive no compensation at all for his performance. Innocent parties could reap windfall gains by voiding contracts they had not performed, but that the guilty party had fully performed.

Not surprisingly, few courts have read the section literally when faced with such inequitable results. In Mills, the Supreme Court commented that when $\S 29(\mathrm{~b})$ is invoked:

Possible forms of relief will include setting aside the merger or granting other equitable relief, but . . nothing in the statutory policy "requires the court to unscramble a corporate transaction merely because a violation occurred." In selecting a remedy the lower courts should exercise " the sound discre-

101 Id at 40.

${ }^{102}$ Giving a tortious interferer a defense would effectively privilege third parties to void contracts through wrongful means when they could not do so through litigation.

${ }^{103}$ See Occidental Life, 496 F2d at 1265 (noting that if read literally $\S 29$ (b) would have a "devastating meaning"); Pearlstein, 429 F2d at 1149 (Friendly dissenting) (noting the "Draconian language" of $\S 29$ (b) but reading it as legislative direction to apply "common-law principles of illegal bargain"). 
tion which guides the determinations of courts of equity" " keeping in mind the role of equity as "the instrument for nice adjustment and reconciliation between the public interest and private needs as well as between competing private claims."104

Courts, in following this language from Mills, should keep in mind that $\S 29(\mathrm{~b})$ is a remedial provision designed to advance the substantive provisions of the securities laws and regulations. In most cases involving individual protection rules, the party seeking to void the contract will also have a private right of action for damages. Thus, if an action for damages will make the injured party whole, and voiding the contract will be inequitable, courts should not invoke § $29(\mathrm{~b})$.

Such was the case in Occidental Life $v$ Pat Ryan where voiding the contract because of a Rule $10 \mathrm{~b}-5$ violation would have resulted in the plaintiff "gain[ing] double its amount of damages," a result that "would hardly be equitable."10s The court relegated the plaintiff to his legal remedy, refusing "to nullify a contract which has been executed. . . . especially ... where the parties have other remedies at their disposal which will produce an equitable result." 106 The court interpreted $\S 29(\mathrm{~b})$ in light of the whole panoply of provisions of the 1934 Act and concluded that "[s]uch an application of Section 29(b) would serve to nullify those other remedies and substitute a penalty provision."107

In other cases, courts may not face the question of whether to void a contract or provide damages. Instead, the case may present a situation where damages are either unavailable or would be diffcult to calculate, and where voiding the contract will be inequitable because there has been substantial performance. In these cases, courts should use their equitable powers to fashion a remedy to fit the case at hand.

The Fifth Circuit did just that in Regional Properties $v$ Fin. \& Real Estate Consult.. ${ }^{108}$ There, a disbarred lawyer sold limited partnership interests in real estate holdings to investors despite the fact that he had not registered as a securities broker/dealer as required by $\S 15(\mathrm{a})(1)$ of the 1934 Act. $^{109}$ The general partners

\footnotetext{
104396 US at 386 (citations omitted).

${ }^{205} 496$ F2d at 1267.

${ }^{108}$ Id (emphasis in original).

$107 \mathrm{Id}$.

${ }^{108} 678$ F2d 552 (5th Cir 1982).
}

109 USC $\$ 780(a)(1)$ (1982) provides in relevant part that "It shall be unlawful for any broker or dealer ... to ... induce ... the purchase or sale of, any security ... unless such broker or dealer is registered in accordance with subsection (b) of this section." 
brought suit when they discovered that the disbarred lawyer was not a registered broker/dealer, but only after the defendant had been paid a substantial amount and had rights to several hundred thousand dollars in an escrow account. In fashioning a remedy under $\S 29(\mathrm{~b})$, the district court allowed recovery of the escrowed funds but denied recovery of fees already paid to the defendant, reasoning that he had done the work and should be compensated. ${ }^{110}$

The Fifth Circuit approved this result. It held that:

The fact that public policy embodied in the securities laws prohibits enforcement of the contract is not alone a sufficient reason to allow even an innocent party to retain an unjust enrichment at the expense of a culpable one. ... When the services contracted for have been performed by an unlicensed person, courts have "nearly always" denied restitution of payments made for such services. Because he has done the work promised, the unlicensed person who received the fee is not unjustly enriched. The person who paid his fee has received actual services. The law, therefore, leaves the parties where it found them. ${ }^{111}$

The court decided that since the escrowed funds were to be used for unpaid debts, "as between Regional [the plaintiff] and Financial [the defendant], this loss ... should fall on the violator of the Act."112

This adjustment of remedies is consistent with the Supreme Court's decision in Mills. It is unlikely that in enacting $\S 29(\mathrm{~b})$ Congress meant greater losses to fall on violators based upon fortuities (such as how much performance had been rendered by the violating party when suit was brought). It is also unlikely that Congress meant for minor violations to upset enormous transactions. It makes more sense for the courts to fashion remedies to fit the facts of each case than for them to adopt a simplistic literal reading that does not advance the real policy of the rules.

That is not to say that $\S 29(\mathrm{~b})$ 's voiding policy should never be used. In some cases the injured party discovers the securities violation when there has been little or no performance. The injured party then refuses to perform, pointing to the securities law violation, and is sued for breach of contract. The injured party can then

\footnotetext{
$110678 \mathrm{~F} 2 \mathrm{~d}$ at $555-57$.

111 Id at 564 (citations omitted).

112 Id at 565.
} 
raise $\S 29(b)$ defensively.

Such a situation arose in Sundstrand Corp. $v$ Sun Chemical Corp. ${ }^{113}$ Upon discovering Rule $10 \mathrm{~b}-5$ violations, Sundstrand sued for damages and refused to perform on a stock purchase option agreement. The defendant counterclaimed for damages for breach of contract and Sundstrand raised $\S 29(\mathrm{~b})$. The court awarded damages to the plaintiff and held that the $10 \mathrm{~b}-5$ violations excused performance on the stock purchase agreement. ${ }^{114}$

This is a sound result because there had been no performance before Sundstrand elected to void the contract. Thus, the violating party lost the benefit of the bargain, but did not lose anything more. The non-violating party is excused from performing an agreement procured by illegality, but receives no windfall gain from not having to pay for already completed performance. The result is, therefore, equitable without any further adjustments from the court.

With this in mind, it is doubtful that in the Texaco case a court would have "unscrambled" the Pennzoil/Getty agreement because of the alleged Rule $10 \mathrm{~b}-13$ violation at issue. All shareholders were to have received the same price under the Pennzoil/ Getty contract. The only difference was that the Getty Museum might have received its money earlier and benefitted from whatever interest accrued on those funds between the time it was paid and the time the tendering shareholders were paid. In the context of a transaction the size of the Pennzoil/Getty merger, this difference is negligible. A more equitable remedy would have been to force Pennzoil to pay the tendering shareholders the same amount of interest that the Museum received. ${ }^{115}$

\section{Section 29(B) and State Illegality Defenses}

Section 29(b) may not be the only defense available for parties

113553 F2d 1033 (7th Cir 1977).

114 Id at 1051.

${ }^{116}$ It is possible that any added benefit to the Getty Museum would have been offset by other matters. As the Texas appeals court noted:

[T] he agreement called for the same price to be paid per share for all selling shareholders. ... There was testimony that the Museum, and indeed all parties, insisted that all shareholders were to be treated equally in the Pennzoil transaction, and that the parties all proceeded on this assumption. Pennzoil points out that if the Museum had been paid for its shares before the public shareholders, any benefit that it might have received from having its shares purchased sooner would have been offset by payment of Getty's first quarter dividend to those remaining shareholders.

729 SW2d at 807. 
seeking to void contracts illegal under the securities laws. Section 29 (b) is often raised defensively in breach of contract actions. Since contract actions are state law causes of action, the defenses to such actions are usually controlled by state law. Many states recognize a defense when the underlying contract violates the law in some way. ${ }^{116}$ This section explores the interplay between these state law illegality defenses and $\S 29(\mathrm{~b})$. Specifically, it looks at the question of whether a state illegality defense is relevant at all when it is a federal law, such as Rule 10b-5, that makes the contract illegal. While state courts must allow parties to whom $\S 29(\mathrm{~b})$ provides a defense to avoid a contract, the question explored here is whether state courts can also allow parties who would not have a federal defense under $\S 29$ (b) to use state illegality defenses to avoid a contract illegal under federal law.

\section{A. Federal Precedent}

One reason a state may not be able to expand the group of parties who can take advantage of illegality under the federal securities laws is simply that these laws were passed to advance certain federal policies and they provide exclusively for federal beneficiaries. Giving a defense to individuals not covered by $\S 29(\mathrm{~b})$ may not advance these policies. However, in the absence of a conflict with the purposes of the federal statute, a state would not be refusing to enforce federal law, but would be expanding the effect of the securities laws by allowing the defense. The question raised, then, is whether states can give additional effect to federal statutes.

Federal precedent indicates that they cannot. In Kelly $v$ Kosuga, for example, the Supreme Court stated that "state law governs in general the rights and duties of sellers and purchasers of goods, [but] ... the effect of illegality under a federal statute is a matter of federal law . . . even in diversity actions in the federal courts after Erie R. Co. v. Tompkins."117 Kelly involved a contract action in which the defendant attempted to interpose the state law

${ }^{116}$ For cases involving state illegality defenses, see Schmidt $v$ Town of Alvin, 429 NW2d 541, 145 Wis 2d 806 (Wis App 1988); Accountemps v Birch Tree Group, 539 A2d 1261, 224 NJ Super 163 (Sup Ct NJ 1988); Daye v Roberts, 365 SE2d 660, 89 NC App 344 (NC Ct App 1988); McGinley v Massey, 525 A2d 1076, 17 Md App 352 (Ct App MD 1987). For cases involving $\S 29(\mathrm{~b})$ raised in state courts, see Hinnant $v$ American Nat'l Bank, 406 S2d 1206 (Ct App Fla 1981); Shearson Hayden Stone, Inc. v. Feldman, 439 NYS2d 975, 109 Misc 2d 403 (Civ Ct NY 1980); Chicago Corp. v. Jordan, 411 NYS2d 116, 96 Misc 2d 1040 (NY S Ct 1978); UFITEC v Carter, 571 P2d 990, 20 Cal 3d 238 (1977).

${ }^{117} 358$ US 516, 519 (1959) (citations omitted). 
defense of illegality based on a violation of the federal Sherman Act. The Court held that "the Sherman Act's express remedies could not be added to judicially by including the avoidance of private contracts as a sanction."118 Similarly, allowing parties to raise a state illegality defense when $\S 29$ (b) does not afford them a federal defense would amount to judicial expansion of the express remedies contained in the securities laws. ${ }^{19}$

In Rothberg $v$ Rosenbloom, the Third Circuit applied this general reasoning to a contract action involving the securities laws. ${ }^{\mathbf{1 2 0}}$ In that case, the plaintiff brought suit seeking recovery on two promissory notes that the defendant claimed arose out of transactions in violation of Rule $10 \mathrm{~b}-5$. The district court held that the claim was barred by the Pennsylvania illegality defense and by the federal in pari delicto defense. The Third Circuit reversed, holding that the state illegality defense was irrelevant and that federal law controlled:

We see no need to consider the defense of illegality under Pennsylvania law because the public policy, even as alluded to by the district court, is one that underlies federal securities law, not Pennsylvania law. Therefore, the analysis with respect to the illegality defense is governed by federal law, not state law. ${ }^{121}$

\section{B. Concern for Uniform Application of Federal Law}

In Wisconsin Dept. of Industry $v$ Gould Inc., ${ }^{122}$ the Supreme Court relied on a concern for the uniform application and effect of federal law to invalidate a state labor policy. Wisconsin had adopted a policy of barring repeat violators of the National Labor Relations Act from doing business with the state. The Court struck down the Wisconsin policy holding that the NLRA prevented states "not only from setting forth standards of conduct inconsistent with the substantive requirements of the NLRA, but also

118 Id (citing D. R. Wilder Mfg. Co. v Corn Products Refining Co., 236 US 165 (1915)).

118 "When a federal statute condemns an act as unlawful, the extent and nature of the legal consequences of the condemnation, though left by the statute to judicial determination, are nevertheless federal questions, the answers to which are to be derived from the statute and the federal policy which it has adopted." Sola Electric Co. $v$ Jefferson Co., 317 US 173, 176 (1942).

120808 F2d 252 (3d Cir 1986).

${ }^{121}$ Id at $254 \mathrm{n} 2$. The concurring and dissenting judges agreed. See id at 259 (Seitz concurring), and id at 261-62 (Sloviter dissenting).

122475 US 282 (1986). 
from providing their own regulatory or judicial remedies for conduct prohibited ... by the Act."123 Such additional remedies were prohibited "because "the range and nature of those remedies that are and are not available is a fundamental part' of the comprehensive system established by Congress." 124 While the Court finds preemption in the labor law context more readily than it does in other contexts, ${ }^{125}$ the logic of forbidding additional state remedies for federal law violations seems to apply generally and is consistent with the Third Circuit's holding in Rothberg.

\section{Limits on State Regulatory Power}

An additional justification for a limitation on the state illegality defense stems from the proposition that a state should be without power to punish conduct that it cannot regulate. While states are free to regulate the securities aspects of some transactions, ${ }^{126}$ the Commerce Clause limits state securities law regulations. A state can only regulate securities when there is a significant nexus between the corporation being regulated and the state. Thus, in Edgar $v$ MITE Corp., ${ }^{127}$ the Court invalidated an Illinois regulation of tender offers on Commerce Clause grounds because the law applied any time 10 percent of the shares of a corporation were owned by Illinois residents. Since the law could apply when 90 percent of the shareholders resided out of state, it could conceivably "regulate a tender offer which would not affect a single Illinois shareholder." 128 Thus, the "Illinois statute [was] a direct restraint on interstate commerce and ... [had] a sweeping extraterritorial effect." 128

In upholding a somewhat similar Indiana statute against Commerce Clause attack in CTS Corp. $v$ Dynamics Corp. of America, ${ }^{130}$ the Court distinguished MITE on the grounds that the "Illinois law . . a applied as well to out-of-state corporations as to

123 Id at 286.

124 Id at 287, quoting Motor Coach Employees v Lockridge, 403 US 274, 287 (1971).

${ }_{126}$ Compare Golden State Transit v Los Angeles, 475 US 608 (1986) (city prevented from conditioning extension of franchise agreement on settlement of labor dispute), with CTS Corp. v Dynamics Corp. of America, 481 US 69 (1987) (Williams Act does not preempt state anti-takeover statute).

126 Federal securities laws do not occupy the field of securities such that all state securities regulation is pre-empted. See CTS Corp., 481 US 69.

127457 US 624 (1982).

128 Id at 642 .

129 Id.

130481 US 69 (1987). 
in-state corporations. We agree that Indiana has no interest in protecting non-resident shareholders of non-resident corporations. But this Act applies only to corporations incorporated in Indiana."131 Thus, only the state of incorporation of the target company can regulate tender offers. If the state whose contract law is being applied is not the state of incorporation, the state has no power to regulate the tender offer at issue. Unless the state of incorporation has passed legislation outlawing the same conduct as the federal regulation, as well as a broader analog to $\S 29(\mathrm{~b})$, no government with the power to regulate the securities aspects of the transaction has granted a defense to a breach of contract action. A state with no power to issue a regulation has no power to punish a violation of the regulation beyond the punishment provided by the federal government.

\section{The Impact of Merrell Dow}

One could argue that the Supreme Court's recent decision in Merrell Dow Pharmaceuticals Inc. $v$ Thompson ${ }^{\mathbf{1 3 2}}$ contradicts the pre-emption analysis just presented. In Merrell Dow, the plaintiffs claimed that Dow was liable under state law theories of negligence, breach of warranty, strict liability, fraud, and gross negligence in their manufacture and distribution of the drug Benedectin. The complaint alleged that children of mothers ingesting the drug were born deformed. ${ }^{133}$ The core of the plaintiff's' theory of liability was that "the drug Benedectin was 'misbranded' in violation of the Federal Food, Drug, and Cosmetic Act (FDCA) ${ }^{134}$. . . because its labeling did not provide adequate warning that its use was potentially dangerous." 135 The plaintiffs alleged that the violation of the federal statute created a rebuttable presumption of negligence under state law. ${ }^{136}$ The Merrell Dow Court "conclude[d] that a complaint alleging a violation of a federal statute as an element of a state cause of action, when Congress has determined that there should be no private federal cause of action" does not arise under federal law, and thus let stand the plaintiff's state law claim. ${ }^{137}$

This holding might be read as allowing states to recognize

\footnotetext{
131 Id at 93 (emphasis in original).

132478 US 804 (1986).

${ }^{133}$ Id at 805 .

${ }^{334} 21$ USC $\S 301$ et seq (1982).

136478 US 805-06.

${ }^{136}$ Id at 806.

${ }^{137}$ Id at 817.
} 
state causes of action for the violation of federal statutes even when the federal government has chosen not to provide such causes of action. This would seem to contradict the argument that states cannot provide broader remedies for the violation of federal law than the federal government has provided.

Initially, however, several points distinguish the Merrell Dow holding from the question of whether a state can provide additional remedies for violation of a federal statute. First, in Merrell Dow the state did not provide any remedy for a violation of the FDCA. The statute was merely used as a proxy for a standard of ordinary care. Since the presumption of negligence was rebuttable, the plaintiff could have proved a violation of the statute and still not recovered. Thus, a violation of the statute, while illegal under federal law, may not have been negligent under state law. Second, the question at issue in Merrell Dow was whether there was original federal court jurisdiction because of the use of federal statute to set the standard of care, not whether federal law controlled the construction of the statute. ${ }^{138}$ Indeed, the Court supported the arguments concerning the limits on state regulatory power by making clear that federal law did control the construction of the statute:

To the extent that [Merrell Dow] is arguing that state use and interpretation of the FDCA pose a threat to the order and stability of the FDCA regime, petitioner should be arguing, not that federal courts should be able to review and enforce state FDCA-based causes of action as an aspect of federal-question jurisdiction, but that the FDCA pre-empts state court jurisdiction over the issue in dispute. Petitioner's concern about the uniformity of interpretation, moreover, is considerably mitigated by the fact that, even if there is no original district court jurisdiction for these kinds of action, this Court retains power to review the decision of a federal issue in a state cause of action. ${ }^{139}$

The Court emphasized this distinction between original federal court jurisdiction and federal control over interpretation of a federal statute by quoting the proposition, from Moore $v$ Chesapeake \& Ohio R. Co. that:

${ }^{138}$ If the presumption were irrebuttable, however, the case would be different since then the state would be creating a private remedy for violation of a federal statute despite Congress's intention that there be no private remedy.

${ }^{139}$ Merrell Dow, 478 US at 816 (footnotes omitted). 
[q]uestions ... relating to the scope or construction of the Federal Safety Appliance Acts are, of course, federal questions which may appropriately be reviewed in this Court. . . . But it does not follow that a suit brought under [a] state statute ... [that] brings within the purview of the statute a breach of the duty imposed by the federal statute, should be regarded as a suit arising under the laws of the United States and cognizable in the federal court in the absence of diversity of citizenship. ${ }^{140}$

Thus, Merrell Dow stands for the proposition that not all causes of action that contain federal questions arise under federal law. However, it also supports the notion that a state court's decision as to the scope and construction of a federal statute is controlled by federal interpretation. Thus, more expansive interpretations by the states are not permitted.

Additional support for the theory that Congress intended the federal courts to control the interpretation of the securities laws can be garnered from the fact that Congress vested the federal courts with "exclusive jurisdiction of violations of this chapter or the rules and regulations thereunder, and of all suits in equity and actions at law brought to enforce any liability or duty created by this chapter or the rules and regulations thereunder."141 The only way that issues touching upon the federal securities laws or rules can ever be raised in a state court is defensively. This provides evidence of a congressional intention to promote a uniform interpretation of the rules.

When Congress chooses a range of statutory remedies, it balances the need to ensure compliance with the statute with the need to avoid over-deterrence that might cause people to avoid legitimate, beneficial activities. In the case of $\S 29(\mathrm{~b})$, for example, expanding the class of people who could take advantage of a violation of Rule 10b-13, might over-deter tender offerors by opening up the possibility of lengthy and costly litigation with third parties even if the tender offer is successful. A state's expansion of remedies could upset the balance the federal policy has struck.

\section{Conclusion}

Courts should avoid adopting per se rules when deciding when

${ }^{140}$ Id at $816 \mathrm{n}$ 14, quoting Moore $v$ Chesapeake \& Ohio R. Co., 291 US 205, 214-15 (1934).

${ }^{141} 15$ USC $\S 78$ aa (1982). 
and how to apply $\S 29(\mathrm{~b})$. Since $\S 29(\mathrm{~b})$ is a remedial provision, it advances no substantive policy of its own. Instead, the substantive policy is contained in the other sections of the Exchange Act and in rules and regulations passed pursuant to the Act. The policies underlying these rules should guide courts in applying $\S 29(\mathrm{~b})$.

This comment has proposed a broad framework for implementing $\S 29(\mathrm{~b})$ in the many different contexts it could be invoked. Additionally, the comment has discussed the proper approach courts should take in fashioning remedies under $\S 29(\mathrm{~b})$ so as to promote equitable outcomes. Lastly, the comment has argued that $\S 29$ (b) exclusively governs which parties can take advantage of illegality under the federal securities laws in breach of contract actions and that state illegality defenses cannot be used to broaden this class. 
